\title{
Charles Darwin, Alfred Russel Wallace, and the Evolution / Creation of the Human Brain And Mind
}

\section{Charles Darwin, Alfred Russel Wallace y la Evolución / Creación del Cerebro y Mente Humana}

\author{
Stephen E. Glickman \\ Departments of Psychology and Integrative Biology \\ University of California, Berkeley, USA \\ E-mail: glickman@calmail.berkeley.edu
}

\begin{abstract}
Charles Darwin and Alfred Russel Wallace independently discovered natural selection, and a set of common experiences surely contributed to that event. But, there were also major differences in their life-experience as collectors and travelers, their socio-political commitments, and their personal styles. The present paper is focused on, what is, perhaps, the most fundamental area of disagreement between Darwin and Wallace: the evolution of humanity. Darwin argued that human evolution could be explained by natural selection, with sexual selection as a significant supplementary principle. Wallace always had doubts about sexual selection, and ultimately concluded that natural selection alone was insufficient to account for a set of uniquely human characteristics. Among these characteristics, the size and complexity of the human brain, found in all extant human races, occupied a central position. Wallace proposed that some new agent had to be invoked, in order to explain the existence of a brain, that could support the common intellectual activities of European culture, but was not (in his view) required to support survival and reproduction in the people that he lived with in the tropics. Wallace's interest in the human brain, and in a materialistic view of brain function, was a natural outcome of an early and enduring belief in Phrenology. Once he had identified the "paradoxical" cerebral hypertrophy of non-European racial groups, Wallace's commitment to "adaptationism," meant that a supplementary principle had to be invoked in order to account for that hypertrophy. The invocation of a higher power, and/or supreme intelligence, that intervened to create modern humanity, was undoubtedly facilitated by his interest in, and conversion to, spiritualism. Wallace's abandonment of natural selection and sexual selection, as the sole agents of human evolution, set him apart from Darwin - and that, inevitably raises questions about the reasons for Wallace's defection. Among Wallace's personal traits was a consistent attraction to unpopular causes, including phrenology and spiritualism. Just as he had been attracted to evolutionary ideas, against the prevailing views of his time, so he diverged, from his fellow "Darwinists," by invoking the action of a "Higher Intelligence" to account for the nature of our species.
\end{abstract}

KEYwORDS: Darwin, human evolution, phrenology, spiritualism, Wallace.

\section{RESUMEN}

Charles Darwin y Alfred Russel Wallace descubrieron de forma independiente la selección natural; seguramente ciertas experiencias en común posibilitaron dicho evento. Sin embargo, hubo diferencias mayores en sus experiencias de vida como colectores y viajeros, en sus compromisos socioculturales y sus estilos personales. El presente ensayo se centra en, lo que quizás constituya, el área de mayor desacuerdo entre Darwin y Wallace: la evolución de la humanidad. Darwin argumentó que la evolución humana podía explicarse mediante selección natural, con la selección sexual como un principio suplementario importante. Wallace siempre tuvo dudas sobre la selección sexual, y concluyó que la selección natural por sí sola era insuficiente para dar cuenta de un grupo de características único de los humanos. Entre éstas, el tamaño y complejidad de la mente humana, presente en todas las razas, ocupó un lugar central en

Pp. 32-41 en D’Elía, G. 2009. Una celebración de los aniversarios darwinianos de 2009. Gayana 73 (suplemento): 1-88. 


\begin{abstract}
sus argumentos. Wallace razonó que agentes adicionales debían ser invocados para explicar la existencia de una mente, que podía dar cuenta de las actividades intelectuales de la cultura europea, pero que no era (en su visión) requerida para explicar la supervivencia y reproducción de las personas con las que él había vivido en los trópicos. El interés de Wallace en la mente humana, y en una visión materialista del funcionamiento de la misma, fue una consecuencia natural de su creencia en la frenología. Una vez que visualizó la paradójica hipertrofia cerebral de los grupos raciales no europeos, el compromiso de Wallace con el "adaptacionismo" derivó en la necesidad de invocar un principio suplementario para explicar dicha hipertrofia. La invocación de un poder superior, y/o de una inteligencia suprema, que intervino para crear la humanidad moderna, fue propiciada indudablemente por su interés, a la vez que conversión, en el espiritualismo. El abandono de Wallace de la selección natural y sexual, como los únicos agentes detrás de la evolución humana, lo apartaron de Darwin; hecho que inevitablemente aparejó incertidumbre sobre los motivos de su deserción. Entre las características personales de Wallace figuraba una atracción consistente por causas impopulares, incluyendo la frenología y el espiritualismo. Así como se sintió atraído por las ideas evolutivas, contrarias a las ideas prevalecientes de su tiempo, se alejo de sus colegas darwinistas al invocar la acción de una "inteligencia superior" para dar cuenta de la naturaleza de nuestra especie.
\end{abstract}

Palabras clave: Darwin, frenología, espiritualismo, evolución humana, Wallace.

\section{INTRODUCTION}

Charles Darwin and Alfred Russel Wallace are justly celebrated as the co-discoverers of the Theory of Natural Selection. And, as detailed below, they had an admirable personal relationship. But, there were scientific disagreements. In his autobiography, published when Wallace was 82 years of age, Wallace listed four areas, as: "Representing the Chief Differences of Opinion Between Darwin and myself (Wallace 1905: 16)." First on Wallace's list was: "The Origin of Man as an Intellectual and Moral Being." - with Darwin committed to human evolution through natural selection and, Wallace invoking intervention of a "Power," or a "Higher Intelligence," in order to account for the origin of our species. Other points of disagreement listed by Wallace included: sexual selection, the events that resulted in distribution of arctic plants outside their usual range, and Darwin's theory of inheritance, Pangenesis; the latter was first accepted by Wallace, but subsequently rejected (Wallace 1905: 16-22).

It is the first difference-of-opinion that forms the central concern of this article. ${ }^{1}$ In 1864 , Wallace

\footnotetext{
${ }^{1}$ A set of excellent full-length biographies of Alfred Russel Wallace have appeared since 2000 (Raby 2001; Shermer 2002; Slotten 2004). Each biographer has dealt with the Darwin-Wallace split over human origins, and presented many of the facts contained in this paper in much greater detail. But, the emphases vary from one writer to the next, presumably in accord with their interests and background. My own graduate education in brain and behavior, and work in comparative psychology, inevitably led to a focal interest in the role of evolutionary ideas in comparative psychology and (what is now called) behavioral neuroscience. To this
}

had published a detailed paper on human evolution through natural selection, which received a very positive reception from Darwin, who had limited his own references to "Man" in The Origin of Species. But, in 1869, Wallace reversed course, arguing that consideration of certain human characteristics, forced the conclusion that, in contrast to all other extant species, human beings had been created by a "higher intelligence." The focus of Wallace's argument in the 1869 article, and in a more extensive chapter published the following year (Wallace 1870a), involved the human brain and mind. Some writers considering his defection from evolutionary orthodoxy have focused on Wallace's conversion to spiritualism in the years preceding the 1869 paper in The Quarterly Review (e.g., Raby 2001). Although I am convinced that spiritualism played a major role, in the pages that follow, I follow Frank Turner (1974), in emphasizing the impact of Wallace's commitment to phrenology, as a critical component of the events that led Wallace to reject natural selection as the sole determinant of human origins. The path that led to the disagreement between Darwin and Wallace over human evolution was lengthy and complex.

\section{The Co-Discoverers}

In 1960, the sociologist Robert Merton, published

point, my writing about Wallace and Darwin has been limited to a single paper on the impact of evolutionary ideas in the development of comparative psychology and adjacent biological disciplines (Glickman 1985). In the future, I plan to expand the neurological themes contained in the present article. 
an influential account of priority conflicts in scientific discovery (Merton 1960). In an article filled with tales of eminent scientists behaving in absolutely despicable fashion across the centuries, in order to preserve their priority, the Darwin Wallace episode was unique, and represented the way that we all wanted scientists to behave: with mutual respect and consideration that persisted for their lifetimes, even through periods of exceptionally fundamental disagreement.

Although the idea of evolution, that is, the notion that species could be transmuted into other species through natural processes, had been commonly discussed in the early years of the 19th century, both theological doctrine and scientific opinion overwhelmingly favored the fixity of species. Darwin's task was the discovery of an adequate mechanism and references to natural selection appear in his notebooks as early as 1838 . By the 1840 's he had written several sketches of his ideas and shared his insights, first with the botanist Joseph Hooker, and later with the geologist Charles Lyell. When Wallace independently arrived at the principle of natural selection in February, 1858, while collecting specimens in the Spice Islands, he mailed the resulting manuscript to Darwin, with whom he had corresponded, and who he knew to be working on the species question. A letter from Wallace accompanied the manuscript, requesting that, if Darwin thought it worthwhile, perhaps he might pass the manuscript along to Lyell. The story of Darwin's initial agony over loss of priority and the intervention of Lyell and Hooker, resulting in joint presentation of papers by Darwin and Wallace at a meeting of the Linnean Society on July 1, 1858, has been repeated and analyzed in many venues, including Darwin and Wallace biographers (e.g., Raby 2001; Browne 2002; Shermer 2002; Slotten 2004).

Although some Wallace biographers have suggested that Wallace fell into the hands of the British scientific establishment and was cheated of his priority (e.g., McKinney 1972; Brackman 1980; Brooks 1984), Wallace considered it fair and appropriate (Wallace 1908). He dedicated his major work on the Malay Archipelago (1869) to Charles Darwin "For His Genius and his Works." More than that, he persisted in calling the theory Darwinism (see for example Wallace 1889).
After publication of Wallace's 1864 article on human evolution, Darwin wrote to him, expressing admiration for Wallace's generosity of attribution regarding natural selection. However, he added that: "...but you ought not in the Man paper to speak of the theory as mine; it is just as much yours as mine. One correspondent has already noticed to me your "high-minded" conduct on this head (Darwin to Wallace, May 28, 1864; Marchant 1916: 127)." Wallace replies on May 29 $9^{\text {th }} 1864$ : “As to the Theory of Natural Selection itself, I shall always maintain it to be actually yours and yours only. You had worked it out in details that I would never have thought of, years before I had a ray of light on the subject... All the merit I claim is... having been the means of inducing you to write and publish at once (Marchant 1916: 131)."

\section{Similarities and Differences in Life EXPERIENCE.}

In her monumental biography of Darwin, Janet Browne (2002) notes the similarities in life experience that led Darwin and Wallace to arrive, independently, at the theory of natural selectionincluding reading the geological writings of Charles Lyell, and absorbing the doctrines of Thomas Malthus, on reproductive rates outstripping the increments in resources required for support of human populations. Browne adds: "Even so, the parallels between Wallace's and Darwin's thoughts are no less remarkable for their cultural symmetry. A common political, intellectual and national context linked the two inseparably. Their experiences of geographical exploration and travel in the early imperial era, their various connections with competitive commercial Britain, their mutual appreciation of the marvels of nature and overwhelming desire to understand them..." (Browne 2002: 33).

But, by way of background, we might also note some differences between the lives that were led by Darwin and Wallace. Darwin was 14 years older, and belonged to a wealthy family, which included a grandfather who had written about evolution. He was Cambridge educated, prior to traveling and collecting specimens on the Beagle. Wallace was forced by financial circumstances to leave school at the age of 14 , and worked in the 
building trades, and as a surveyor, with his older brothers. He was, essentially, a self-educated biologist. But, as Peter Raby (2001:14) has described, in the course of Wallace's work with his brother John in London, Wallace was exposed to "...lectures on the teachings of Robert Owen: socialist, secularist, agnostic, and idealist." Those influences were also to play out and develop over the years, and expressed themselves in Wallace's sympathetic attitudes toward the people he met and lived with in South America and the islands of Borneo, Indonesia, and New Guinea.

As noted above, Wallace was also a traveler and collector, spending four years in regions adjacent to the South American Amazon and Rio Negro rivers, and eight years in the Malay Archipelago; he supported his travels by selling specimens to European museums and wealthy collectors. However, I have argued elsewhere that differences in their modes of travel influenced the course of science (Glickman 1985). Darwin traveled as an Englishman surrounded by Englishmen. Even when on distant islands, or continents, Darwin was generally accompanied by crew members of the Beagle, or Europeans who lived in those areas. In contrast, Wallace, after parting from his fellow scientist, Henry Bates, traveled alone in regions adjacent to the Amazon and Rio Negro and lived with the local people. Although, on occasion, he had an English or a Malay, assistant during his travels in the Malay Archipelago, much of the time, he was truly embedded with the residents of various remote villages for long periods of time. This experience, when combined with his socio-political commitments, gave Wallace a very different view of the peoples with whom he lived.

Another important note for this Introduction: Wallace's discovery of natural selection, as the mechanism of evolution, was not an accidental "aha" experience. In the Fall of 1847 Wallace had written to his friend and fellow beetle-collector Henry Bates, stating that: "I begin to feel rather dissatisfied with a mere local collection...I should like to take some one family to study thoroughly principally with a view to the theory of the origin of species (Wallace 1905a: 256-257)." Wallace and Bates left for the Amazon in 1848 with that goal in mind.

\section{WALLACE AND HUMAN EVOLUTION}

1. From “The Origin" to Wallace's 1864 Paper. Darwin's discussion of human evolution in "The Origin of Species" is very limited. In the concluding chapter, Darwin writes: "In the distant future I see open fields for far more important researches. Psychology will be based on a new foundation, that of the necessary acquirement of each mental power and capacity by gradation. Light will be thrown on the origin of man and his history" (Darwin 1859: 488). It fell to Wallace to write the first paper analyzing the role of natural selection in human evolution. With regard to the first question, he argued that we are a single species descended from a common ancestor (which was controversial at that time). The novel central thesis, however, was that, at a certain point in our evolutionary history, the brain became the primary target of selection. Wallace described the outcome with characteristic exuberance:

"At length, however, there came into existence a being in whom that subtle force we term mind, became of greater importance than his mere bodily structure. Though with a naked and unprotected body, this gave him clothing against the varying inclemency's of the seasons. Though unable to compete with the deer in swiftness, or with the wild bull in strength, this gave him weapons with which to capture or overcome both...From the moment when the first skin was use as covering, when the first rude spear was formed to assist in the chase, the first seed sown or shoot planted, a grand revolution was in effect in nature...for a being had arisen that was no longer necessarily subject to change with a changing universe..."

(Wallace 1864: clxvii-clxviii).

Darwin and Lyell wrote approvingly of the paper. Darwin observed that the great central thesis was new to him, and offered Wallace his notes on Man. All three members of the evolutionary trinity (Darwin, Hooker and Lyell) also commented on Wallace's generous attribution of the theory of natural selection to Darwin alone.

2. Wallace's "Defection"

In 1869 , when Wallace was 43 years of age, he 
suddenly rejected Natural Selection as the sole element involved in the genesis of humanity. The vehicle was a review by Wallace of several books on Geology by Charles Lyell in the Quarterly Review, a popular journal of intellectual society. Scanning the Table of Contents for that issue illustrates the extent to which science was embedded in the fabric of English intellectual life, with Wallace' review of serious geological text sandwiched between the poetry of Robert and Elizabeth Barrett Browning and an article on "English Statesman Since the Peace of 1815."

Wallace (1869) now decided that human hairlessness, the structure of the human hand and the vocal power of the larynx could not have contributed to survival and reproduction and therefore could not have been selected. But the center of Wallace' objections involved behavioral attributes and the human brain (the underlining in the following passage is Darwin's, as found in Darwin's copy of the Wallace review, in the Darwin Library at Cambridge University):

"In the brain of the lowest savage, and as far as we yet know, of the pre-historic races, we have an organ so little inferior in size and complexity to that of the highest types (such as the average European), that we must believe it capable, under a similar process of gradual development...of producing equal average results. But the mental requirements of the lowest savages, such as the Australians or the Andaman islanders, are very little above those of many animals... How, then, was an organ developed so far beyond the needs of its possessor? Natural selection could only have endowed the savage with a brain a little superior to that of an ape, whereas he actually possesses one but very little inferior to that of the average members of our learned societies."

On the following page, Wallace discusses “...the structural and mental organs of human speech... and the delicate arrangements of nerves and muscles for its production..." --- and expresses doubts that these would be of any use, "... among the lowest savages with the least copious vocabularies..." Wallace concludes that: "An instrument has been developed in advance of the needs of its possessor."
In addition to the underlined sentences, Darwin writes a large "No" in the upper left margin and inserts four exclamation points in the right margin next to the first passage.

Wallace believed that a solution to this gap, between observed characters and their utility in life, required the intervention of some additional mechanism: "While admitting to the full extent the agency of the same great laws of organic development in the origin of the human race as in the origin of all organized beings, yet there seems to be a Power which has guided the action of those laws (of organic development) in definite directions and for special ends." Later in the article he refers to a "Higher Intelligence" that has guided the laws of development for nobler ends.

\section{DARWIN'S RESPONSE TO WALLACE'S DEFECTION}

There was immediate distress in the Darwin coterie. Darwin himself wrote hoping "that Wallace had not too completely murdered" their joint child. Bates and Hooker wrote distressed letters to Darwin worrying about the impact of Wallace' defection on acceptance of evolution through natural selection. Only Lyell, still concerned about the implications of his own conversion to evolution, found Wallace's arguments of interest in a positive way.

Darwin's offer to Wallace of his notes on man was no longer on the table and his response was contained in two books: "The Descent of Man and Selection in Relation to Sex (1871)," and "Expression of the Emotions in Man and Animals (1873)." In both books Darwin attempts to close the gap between people and animals by locating the precursors of the human mind in the world of extant animals. Previously, the present writer has argued (Glickman 1985) that the split between Darwin and Wallace, over human evolution, energized the publication of these books and provided the ground on which Darwin's disciple, George Romanes, founded a formal comparative psychology (e.g., Romanes 1881, 1883).

Chapters 2, 3 and 4 of The Descent of Man (1871) provide the material that is most directly relevant, as Darwin argues for the continuity of mental processes between men and animals. They are dense 
chapters, filled with a combination of anecdote and observation. Early in Chapter 2, Darwin states that: "My object in this chapter is solely to shew that there is no fundamental difference between man and the higher mammals in their mental faculties" (Darwin 1871: 35). He then proceeds to buttress his claim for continuity of mental processes with examples drawn from personal observation, as when he describes "curiosity" in cercopithecine monkeys, after introducing novel objects into their cage at the zoo (Darwin 1871: 42-43), or describes the existence of reason in South American monkeys by citing the observations of Rengger. The latter reported "...that when he first gave eggs to his monkeys, they smashed them and thus lost much of their contents; afterwards they gently hit one end against some hard body, and picked off the bits of shell with their fingers" (Darwin 1871: 47). Darwin argued that imagination exists in animals, by first linking dreaming with imagination and then noting that "As dogs, cats, horses... have vivid dreams... shewn by their movements and the sounds uttered, we must admit that they possess some power of imagination" (Darwin 1871: 46). Memory was illustrated by recounting an anecdote from the Cape of Good Hope, in which a baboon greeted with joy a man who had been absent for nine months (Darwin 1871: 45). In the first edition of The Descent of Man, Chapter 3 extended these arguments to issues of human development from some lower form, while Chapter 4 was devoted to the role of natural selection in the development of intellectual and moral qualities from primitive tribes to modern civilized humanity. En route, Darwin (1871: 137) answered Wallace directly:

"He has invented and is able to use various weapons, tools, traps, etc., with which he defends himself, kills or catches prey, and otherwise obtains food. He has made rafts or canoes on which to fish or cross over to neighbouring fertile islands. He has discovered the art of making fire, by which hard and stringy roots can be rendered digestible, and poisonous roots or herbs innocuous... These several inventions... are the direct result of the development of his powers of observation, memory, curiosity, imagination and reason. I cannot, therefore, understand how it is that Mr. Wallace maintains, that "natural selection could only have endowed the savage with a brain a little superior to that of an ape." But their views of "savages" were, in fact, very different.

\section{WHY WALLACE DEFECTED}

I believe that there are three elements that account for the Wallace defection over human evolution -and on all three points, he differed from Darwin: 1) Wallace's belief in the equality of intellectual potential in the extant races of man; 2) Wallace's long-standing commitment to phrenology, the materialistic forerunner of modern theories of localization of function in the brain; and 3) Wallace's "adaptationism," or "hyperselectionism"- the conviction that if one observed a trait in an animal, it must have facilitated survival and reproduction.

\section{A Unique View Of The Brains And Intellectual} Potential Of Non-Europeans

First on my list is Wallace's belief in the equality of intellectual potential in all the extant races of man. In arguing with Wallace in the Descent of Man, Darwin had written: "Nor is the difference slight in moral disposition between a barbarian, such as the man described by the old navigator Byron, who dashed his child on the rocks for dropping a basket of sea urchins, and a Howard or Clarkson, and in intellect, between a savage who uses hardly any abstract terms, and a Newton or Shakespeare" (Darwin 1871: 35). ${ }^{2}$

Contrast this view with that of Wallace: "I have lived with communities of savages in South America and in the East, who have no laws or law courts but the public opinion of the village freely expressed. Each man scrupulously respects the rights of his fellows, and any infraction of these rights rarely or never takes place...partly by the influence of public opinion, but chiefly by that natural sense of justice and of his neighbor's right which seems to be, in some degree, inherent in every race of man" (Wallace 1869).

\footnotetext{
${ }^{2}$ John Howard was a leader of the British prison reform movement in the 18th century, while Thomas Clarkson was an English abolitionist who played an instrumental role in eliminating the British slave trade.
} 
Stephen J. Gould (1980) wrote that: "Wallace advanced several arguments for the uniqueness of human intellect, but his central claim begins with an extremely uncommon position for his time, one that commands our highest praise in retrospect. Wallace was one of the few nonracists of the nineteenth century. He really believed that all human groups had innately equal capacities of intellect."

\section{Phrenology}

Second, as originally argued by Frank Turner (1974), Wallace's belief in phrenology played a major role in his departing from Darwin over the action of natural selection on humanity. In "The Wonderful Century" Wallace (1899) devoted the first 15 chapters to describing and commenting on successes of the $19^{\text {th }}$ century. The last six chapters were devoted to the failures of that century, and first on his list was the neglect of phrenology: "I begin with the subject of Phrenology, a science of whose substantial truth and vast importance I have no more doubt than I have of the value and importance of any of the great intellectual advances" (Wallace 1899: 159). Wallace was introduced to Phrenology through reading George Combe, a Scottish lawyer, who converted to phrenology after watching Joseph Spurzheim dissect a human brain and listening to him lecture. In "The Constitution of Man" Combe (1835) discussed the impact of understanding brain function on politics, legislation and education, in directions that would have had great appeal to Wallace. He also provided detailed maps of the surface of the human brain. Human faculties were divided into characteristics shared with animals, and characteristics that are distinctly human, with the former (e.g., amativeness, combativeness and destructiveness) assigned to more ventral portions of the cerebral hemispheres, while a "cathedral of the mind" is constructed for human characteristics, with veneration at the dorsal peak of the cerebral hemispheres (site 14), and most of our cognitive capacities assigned to the frontal lobes. The essential materialism of phrenology linked every human faculty with a particular site in the brain. Concepts regarding "number" were assigned a location in the frontal lobe (site 28) just above and behind the orbit of the eye, with "tune" occupying a more ventral/lateral position in the frontal lobe (site 32). In Appendices to his Travels in the Malay Archipelago (Wallace 1869), Wallace published linguistic compendia for the places that he visited.
As Wallace noted, some of these people had no word in their language for numbers between 10 and 100 , yet he believed that brain structure, presumably including the site supporting concepts of number, was identical in "savages" and "the average members of our learned societies" in England. With regard to the center for "tune," although Wallace did not explicitly link brain structure and human capacity, he notes the musical skills of "Blind Tom," an American slave, with remarkable musical abilities, whose ancestors had been transported from Africa. Wallace (1905, V.II: 428) writes: "Unless Darwin can show me how this latent musical faculty in the lowest races can have been developed through survival of the fittest...I must believe that some other power (than natural selection) caused the development. It seems to me that the onus probandi will lie with those who maintain that man, body and mind, could have been developed from a quadrumanous animals by "natural selection."”

Wallace lived long enough to learn about the brain stimulation and brain lesion experiments of David Ferrier (e.g., Ferrier 1876), that really did demonstrate localization of function in the brain and, through a very selective reading, argues that the maps developed by Ferrier support the maps developed by the phrenologists (Wallace 1899).

\section{3. "Hyperselectionism" Or "Adaptationism" In THe EXTREME}

The final element involves what Stephen Jay Gould (1980) viewed as "Wallace's "Fatal Flaw," that is, what modern evolutionists have sometimes referred to as "hyperselectionism" or "adaptationism." In the contemporary debate between Stephen Jay Gould and Richard Dawkins, with Gould focusing on contemporary characters that have not been specific targets of selection, and may have contributed no particular selective advantage, and Dawkins focusing on selfish genes, controlling characters that convey such advantage, Wallace is Dawkins, not Gould. Michael Shermer (2002) and C. H. Smith (2004) have recently observed that until 1858 , Wallace did not accept a utilitarian view of specific characters. But, in a key paper on "The Principle of Utility" Wallace (1896) made his post-1858 position clear: although correlated characters do exist, the best assumption about any specific observed character is that it conveyed selective advantage, i.e., it conveyed utility. 


\section{Linking Spiritualism And Evolutionary Biology.}

Given his extreme "adaptationism," in conjunction with a fierce commitment to localization of function in the brain, and faced with brains of "savages" that were so similar to the brains of Englishmen in size and structure, Wallace had a problem that he believed could not be explained by natural selection. Any modern cognitive scientist could "explain" Wallace's predicament, by referring to how a brain selected in one habitat might reveal totally novel capacities in a novel habitat. Although this is a credible argument, in his groundbreaking book on Adaptation and Natural Selection, G. C. Williams (1966: 14) commented on the puzzle presented by (what he called) human "cerebral hypertrophy." However, Williams did not proceed to invoke a "Higher Intelligence" to explain the size of the human brain.

Confronted with the difficulties for natural selection, presented by such characteristics as the physical burden imposed by the peacock's tail, Darwin invoked a variety of Sexual Selection, based on the sense of male beauty (possessed by, e.g., female peahens), as an additional principle, complimenting Natural Selection (Darwin, 1871). ${ }^{3}$

Faced with a similar discordance, namely a brain "...so far beyond the needs of its possessor..." Wallace invoked a "Higher Intelligence." Wallace's commitment to spiritualism, as a defining belief system, enabled his attribution of human origins to the intervention of a "Higher Intelligence." His long-standing interest in spiritualism was reinforced when Wallace began attending séances in the 1860 's and spiritualism remained a powerful force for the remainder of his life (Raby 2001; Shermer 2002; Slotten 2004). In 1886, during his tour of the United States, Wallace attended a séance with the philosopher / psychologist William James. As documented by Ruth Brandon (1983), James really

\footnotetext{
${ }^{3}$ The same differences in attitudes toward "savages," between Darwin and Wallace, described elsewhere in this paper, are reflected in the following comments of Darwin on female sexual selection: "When, however, it is said that the lower animals have a sense of beauty, it must not be supposed that such sense is comparable with that of a cultivated man, with his multiform and complex associated ideas. A more just comparison would be between the taste for the beautiful in animals, and that in the lowest savages, who admire and deck themselves with any brilliant, glittering, or curious object" (Darwin 1874/1896: 211)
}

wanted to believe in such phenomena - they would have permitted him to base religion on sensory experience rather than taking it on faith. But, James could never quite convince himself of the reality of such performances. In contrast, Wallace embraced spiritualism. Both his writings about the subject (e.g., Wallace 1875), and the quantity of Wallace correspondence devoted to spiritualism, and housed in the British Museum Library, testifies to the seriousness of his involvement. In her book, "The Spiritualists," Brandon (1983: 121) notes Wallace's defense of mediums that had been exposed as frauds, and describes how he set criteria for proving fraud that made it virtually impossible to discredit the reality of spiritualist phenomena. How Wallace, with his remarkable capacity for critical thought, could have been so taken in by an assortment of charlatans, presents a challenge for all Wallace biographers.

\section{A Rebel With Many Causes.}

Perhaps the answer is to be found in Wallace's unique attraction to unpopular causes. They included mesmerism, phrenology, phreno-mesmerism, spiritualism, land nationalization, socialism and, ultimately, feminism. Wallace's departure from Darwin on Sexual Selection has sometimes been interpreted as opposition to female choice. That is a misreading. Following his commitment to the principle of utility, Wallace wanted women to choose mates for useful reasons, as opposed to mere aesthetics. Accordingly, he advocated educating women so they could select good men, and be freed from the need to marry for economic reasons (Wallace, in Parker 1912). He also led an anti-vaccination movement in $19^{\text {th }}$ century Britain (Shermer 2002: 215-216), and wrote an early article in Nature, opposing government support of science (Wallace 1870b) - not popular positions among his fellow scientists.

Wallace was an ultimate contrarian, as attested to by this quote from a neighbor: "His intellectual interests were very widely extended, and he once confessed to me that they were agreeably stimulated by novelty and opposition. An uphill fight in an unpopular cause, for preference a thoroughly unpopular one, or any argument in favor of a generally despised thesis, had charms for him that he could not resist" (J. W. Sharp, as cited in 
Marchant 1916: 354). Frank Sulloway (1996) has written an influential book on birth order, presenting extensive data to support his argument that later born children occupy a unique "rebellious" niche in their families, and that this rebellious tendency plays out in adult life as receptiveness to radical ideas. Michael Shermer (2002) has, in turn, developed the Sulloway analysis, with respect to Wallace's personality and attraction to unpopular causes. Alfred Russel Wallace is a "poster-person" for Frank Sulloway's rebellious later siblings.

\section{ACKNOWLEDGMENTS}

The author is grateful to Profesor Guillermo D'Elía for inviting submission of this article, and for the many thoughtful suggestions that he provided during the editorial process.

\section{BIBLIOGRAPHY}

Brackman, A. C. 1980. A Delicate Arrangement: The Strange Case of Charles Darwin and Alfred Russel Wallace. Times Books, New York.

Brandon, R. 1983. The Spiritualists. Weidenfeld and Nicolson, London.

Brooks, J. L. 1984. Just Before the Origin: Alfred Russel Wallace's Theory of Evolution. Columbia University Press, New York

Browne, J. 2002. Charles Darwin: The Power of Place. Volume 2. Alfred A. Knopf, New York.

Combe, G. 1835. The Constitution of Man: Considered in Relation to External Objects. John Anderson Jun, Edinburgh. Third Edition.

Darwin, C. 1859. The Origin of Species by Means of Natural Selection. John Murray, London.

Darwin, C. 1871. The Descent of Man and Selection in Relation to Sex. John Murray, London. 2 Volumes.

DARWIN, C. 1872. Expression of the Emotions in Man and Animals. John Murray, London.

DARWIN, C. 1874/1896. The Descent of Man and Selection in Relation to Sex (New Edition, Revised and Augmented. Complete in One Volume). D. Appleton and Company, New York.

Ferrier, D. 1876. The Functions of the Brain. Smith, Elder, \& Company, London.

Glickman, S. E. 1985. Some thoughts on the evolution of comparative psychology. In: A Century of Psychology as Science (Eds. Koch S. \& D.E. Leary ), pp. 738-782. McGraw-Hill, New York.

Gould, S. J. 1980. Wallace's fatal flaw. Natural History 89(1):26-40

Marchant, J. 1916. Alfred Russel Wallace: Letters and Reminiscences. Harper and Brothers, New York.
McKinney, H. L. 1972. Wallace and Natural Selection. Yale University Press, New Haven.

Merton, R. K. 1960. Priorities in scientific discovery: A chapter in the sociology of science. American Sociological Review 22(6):635-659.

PARKER, P. L. 1912. (Ed). Character and Life; a Symposium by Alfred Russel Wallace (and others). Williams \& Norgate, London.

RabY, P. 2001. Alfred Russel Wallace: A Life. Princeton University Press: Princeton, New Jersey.

Romanes, G. J. 1881. Animal Intelligence. Keegan, Paul, Trench, London.

Romanes, G. J. 1883. Mental Evolution in Animals. Keegan, Paul, Trench, London.

Shermer, M. 2002. In Darwin's Shadow: The Life and Science of Alfred Russel Wallace: A Biographical Study on the Psychology of History. Oxford University Press, New York.

Slotten, R. A. 2004. The Heretic in Darwin's Court: The Life of Alfred Russel Wallace. Columbia University Press, New York.

Sмiтh, C. H. 2004. Wallace's unfinished business: The "Other Man" in evolutionary theory. Complexity 10(2):25-32.

Sulloway, F. 1996. Born to Rebel: Birth Order, Family Dynamics and Creative Lives. Pantheon, New York.

Turner, F. M. 1974. Between Science and Religion; the Reaction to Scientific Naturalism in late Victorian England. Yale University Press, New Haven.

Wallace, A. R. 1864. The origin of human races and the antiquity of man as deduced from the theory of "natural selection". The Anthropological Review, 2, clviii-clxx.

Wallace, A. R. 1869. Sir Charles Lyell on Geological Climates and the Origin of Species [Reviews of Principles of Geology (10 $10^{\text {th }}$ ed.), 186768, and Elements of Geology (6 ${ }^{\text {th }}$ ed.) 1865 , both by Sir Charles Lyell]. Quarterly Review 126:359-394.

Wallace, A. R. 1870a. The limits of natural selection as applied to man. In: Contributions to the Theory of Natural Selection. A Series of Essays. MacMillan and Company, London.

Wallace, A. R. 1870b. Government aid to science. Nature 1:288-289.

Wallace, A. R. 1875. Miracles and Modern Spiritualism. Three Essays. James Burns, London.

Wallace, A. R. 1889. Darwinism: an Exposition of the Theory of Natural Selection with some of its Applications. MacMillan, London.

Wallace, A. R. 1896. The problem of utility: Are specific characters always or generally useful? Journal of the Linnean Society Zoology 25:481-496.

Wallace, A. R. 1899. The Wonderful Century: Its Successes and Failures. Dodd, Mead and Company, New York.

Wallace, A. R. 1905. My Life: A Record of Events and Opinions. Chapman \& Hall, London. 2 Volumes.

Wallace, A. R. 1908. Comments on receipt of the 
Darwin, Wallace, and the evolution of the human mind: STEPHEN E. GLICKMAN.

Darwin-Wallace Medal. In: The Darwin-Wallace Celebration, The Linnean Society of London. Longmans Green and Company, London.
Williams, G. C. 1966. Adaptation and Natural Selection: A Critique of Some Current Evolutionary Thought. Princeton University Press, Princeton, N. J. 